\title{
Are age and radiographic features effective on orthodontic alignment of palatally impacted maxillary canines? a retrospective study
}

\section{Purpose}

The purpose of the study was to evaluate the effects of age and radiographic parameters on success of orthodontic alignment of impacted maxillary canines.

\section{Materials and Methods}

The retrospective records of 50 patients (mean age 20.44 years) who had impacted maxillary canines in palatal position were included. The patients was requiring surgical exposure and mechanical orthodontic treatment were divided into two groups as adolescent (age $\leq 18 ; n=24$ ) and adult (age $>18 ; n=26$ ). In both groups, the treatment time and success were evaluated clinically and radiographically.

\section{Results}

Fifty patients between the ages of 13 to 42 ( 12 males and 38 females) with palatally impacted canines were treated with combined surgical-orthodontic approach. Forty-seven teeth (94\%) had reacted to surgical exposure and orthodontic alignment within 16 to 36 months with a mean of 24.81 months. Three of the impacted canines (6\%) were surgically removed because no movement was observed following 10 months of traction forces.

\section{Conclusion}

The distance of the canine tip to the occlusal plane on the lateral cephalometric radiographs have found to be related with the total orthodontic treatment time. Neither the age of the patient nor other clinic and radiographic parameters had influence on the treatment results of alignment of maxillary canines following surgical exposure.

Keywords: Orthodontic alignment; surgical exposure; impacted maxillary canine; radiographic study; retrospective study

\section{Introduction}

Maxillary canines (MCs) are the second most common impacted teeth; with an incidence between $0.9 \%$ and $2.2 \%$ in the general population (13). Impaction of MCs have several complications including esthetic and phonetic compromises, loss in arch length, resorption of the adjacent teeth and pain $(4,5)$. Some clinical symptoms, including the absence of canine bulge in the buccal sulcus, over retained primary cusps, delayed eruption of their permanent tooth and asymmetry of the arch and eruption of the right and left canines, indicate impacted MCs (6).

Treatment opinions could be summarized as no treatment except longterm follow-up by monitoring, autotransplantation of impacted $M C$, extraction of the tooth followed by orthodontic space closure, prosthetic rehabilitation and surgical exposure followed by orthodontic treatment (7). Exposure is a method of simplifying the eruption of impacted or/

\author{
Seda Kocyigit ${ }^{1} \mathbb{D}$, \\ Abdullah Alper $\mathbf{O z}^{2}$ (D), \\ Burcu Bas $^{3}$ (D), \\ Nursel Arici² (D), \\ Selcuk Karahan 4 (D)
}

Presented at: This study was presented as a in the $8^{\text {th }} A C B I D$ International Congress that was held in Antalya, Turkey, 28 May- 1 June, 2012.

ORCID IDs of the authors: S.K. 0000-0002-9259-8526; A.A.O. 0000-0002-1976-9851; B.B. 0000-0003-0593-3400; N.A. 0000-0002-4487-5277; S.K. 0000-0002-4112-8727

'Department of Oral and Maxillofacial Surgery, Ministry of Health Kucukcekmece Oral and Dental Health Center, Istanbul, Turkey

2Department of Orthodontics, Faculty of Dentistry, Ondokuz Mayis University, Samsun, Turkey

${ }^{3}$ Department of Oral and Maxillofacial Surgery, Faculty of Dentistry, Ondokuz Mayis University, Samsun, Turkey

${ }^{4}$ Private Clinic, Samsun, Turkey Corresponding Author: Seda Kocyigit E-mail: dt.sedayilmaz@gmail.com

Received: 6 November 2018 Revised: 11 January 2019 Accepted: 3 February 2019 DOI: 10.26650/eor.20190055 
and malpositioned teeth with orthodontic guiding. It is also the preferred approach for eruption of impacted MCs in medically healthy patients where interceptive measures of dental arch are inappropriate (8). This therapeutic approach is interdisciplinary including orthodontic, periodontal and surgical outcomes.

A grading system has been proposed to determine the severity of the palatal impaction MCs based on the radiographic position. (7). Classification of impacted canines according to radiographic features; the incline of the MC to the midline (a) and long axis of the lateral incisor $(\beta)$, completion of root formation; have been shown to be predictive factors for the durations of orthodontic traction (9). Four main radiographic predictors believed to correlate with the prognosis for exposure and alignment of impacted canines has been described. These four predictors are angulation of long axis to the midline of the canine, vertical position of the crown from the occlusal plane, anteroposterior position of the root apex relative to the midline, and the degree of overlap of the adjacent incisor by the canine crown tip (7).

The purpose of the retrospective study is to evaluate whether these radiological parameters and patient related factors affect the treatment success and time in surgical alignment of MCs. The null hypothesis tested in this project is that the radiological or patient-related variables do not have any effect on the treatment outcome and duration.

\section{Materials and Methods}

\section{Study design}

The present research is a retrospective review of 50 patients with impacted MCs surgically treated at Department of Oral and Maxillofacial Surgery between 2007 and 2011. The study protocol was approved by the ethics committee for medical research (2012/522). The clinical notes and panoramic and cephalometric radiographs of the patients whose impacted MCs were surgically exposed and had following orthodontic alignment were enrolled in this study. The presence of single or both palatal impacted MCs requiring surgical exposure and mechanical orthodontic eruption that has adequate records including complete clinical records and treatment notes with pretreatment radiographs were the inclusion criteria of the study. The exclusion criteria were systemic diseases including metabolic and endocrine disorders and not having adequate clinical and radiographic data. The radiographic evaluation and operations were performed by one surgeon.

\section{Orthodontic treatment}

The teeth were bonded with 0.022-inch slot pre-adjusted MBTTM system brackets. The extractions were made according to the orthodontic treatment plan. After alignment and leveling, an adequate space was opened for impacted canine and then each impacted canine was exposed surgically by removing the palatal flap. The surgical procedures were performed under local anesthesia in all cases by a maxillofacial surgeon. In case of presence of surrounding bone, it would be removed to expose the enamel surface. A button with a chain or wire was bonded onto the crown of the tooth to apply the orthodontic force. Suturing was performed as original position of tissue allowing the chain or wire extending into the oral cavity. After the healing period of approximately 10 days, orthodontic traction was applied. The orthodontic force was applied with ballista spring or elastic chains. When the tooth was visible, continuous force was applied with light $\mathrm{NiTi}$ arch wires to align the teeth. Treatment was finished and the canine was extracted when no response to traction was occurred in 9-10 months.

\section{Study variables}

The following clinical data were analyzed: age and gender, classification of occlusion, total orthodontic treatment time, complications including; resorption of the roots of adjacent teeth and secondary surgery due to the button breakage; extraction of canine. The following radiographic data were analyzed: canine angulation (a): the angle between tooth's longitudinal axis and the vertical reference line (midline) (Figure 1) (10), the distance from the canine tip to its target point on the occlusal plane (Figure 2), the rate of root formation, the mesiodistal position of the canine tip in relationship to the adjacent lateral incisor (Figure 3) (11).

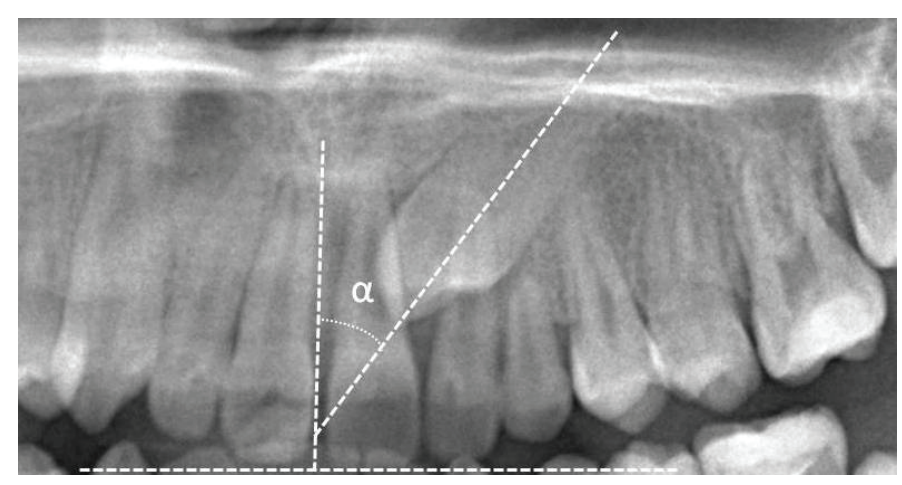

Figure 1. Determination of canine angulation on panoramic radiograph. The angle between its longitudinal axis and the vertical reference line. Grade 1: $0^{\circ}-15^{\circ}$; Grade 2: $16^{\circ}-30^{\circ}$; Grade $3 \geq 31^{\circ}$.

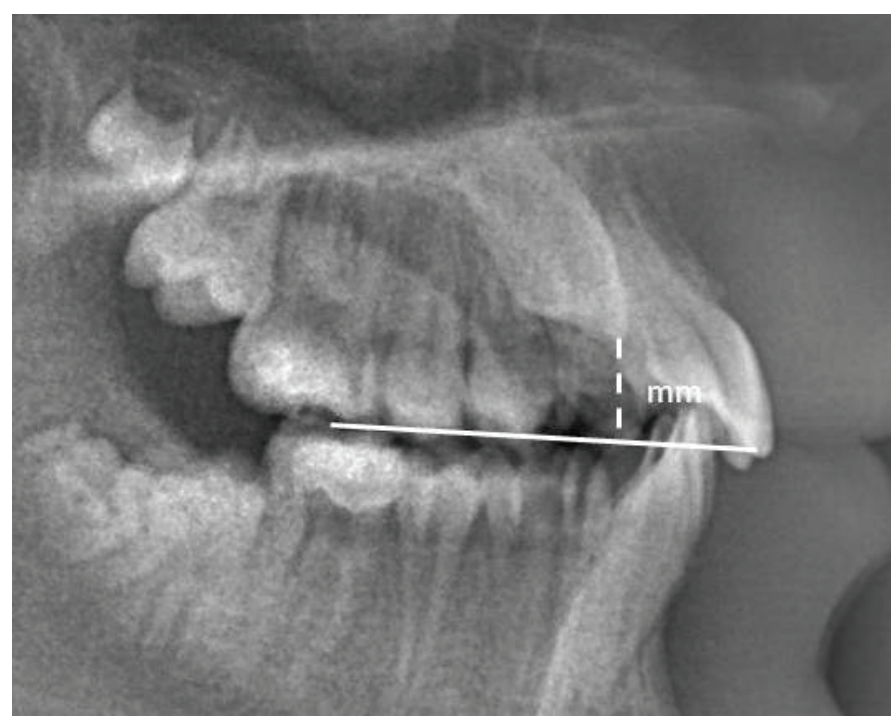

Figure 2. The measurement of the distance from the canine tip to its target point on the occlusal plane on cephalometric radiography. 


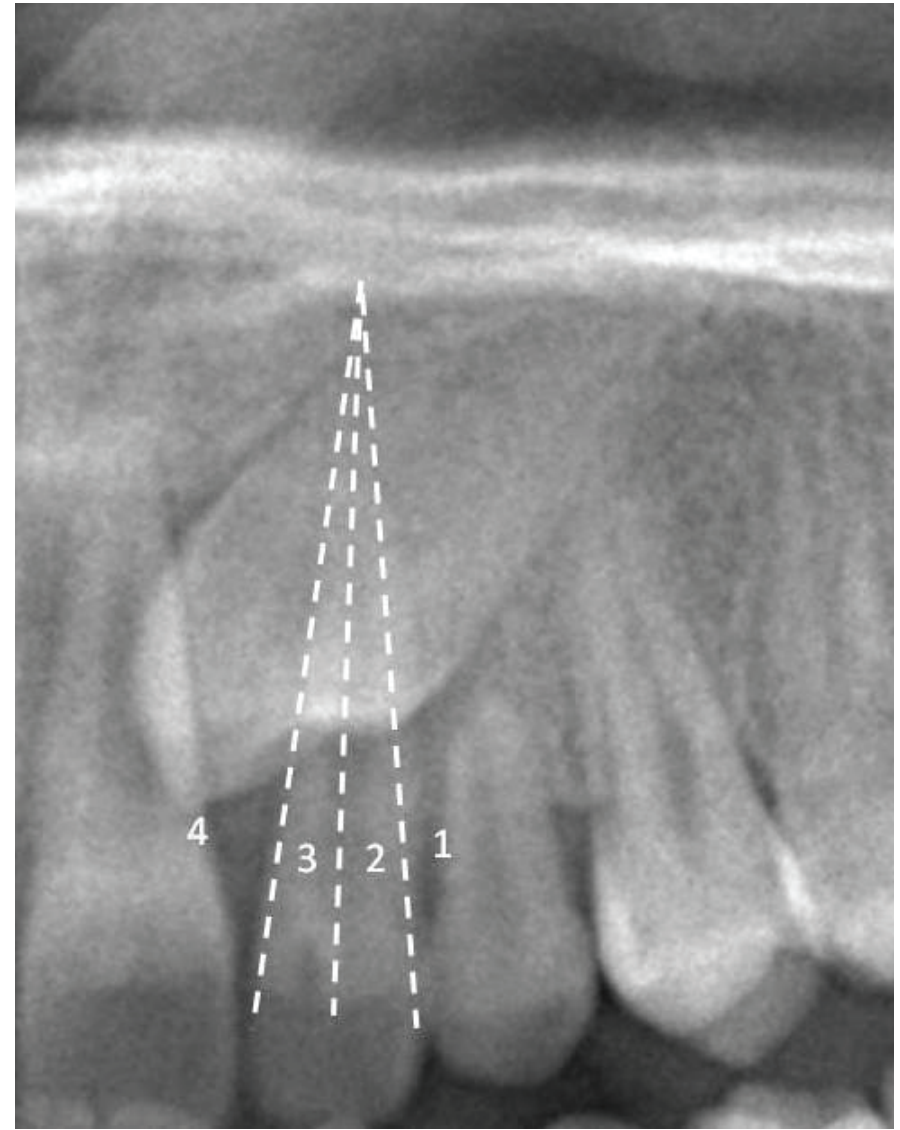

Figure 3. The determination of mesiodistal position of the canine tip in relationship to the adjacent lateral incisor on panoramic radiography. Grade 1: No horizontal overlap. Grade 2: Less than half the root width. Grade 3: More than half, but less than the whole root width. Grade 4: Complete overlap of root width or more.

\section{Statistical analysis}

The collected data from all groups were imported to Statistical Package for Social Sciences (SPSS Inc, Version 13.0, Chicago, LL, USA), the predefined level of statistical significance was $p=0.05$. The statistical analysis of radiographic predictors on treatment duration and success was performed using one way analysis of variance (ANOVA) and Pearson correlation analysis.

\section{Results}

The clinical and radiographic data of 50 patients (38 females, 12 males) who had combine surgical and orthodontic treatment for their impacted MCs between 2007 and 2011 were collected. The patients were divided into two groups as adolescent (age $\leq 18 ; n=24$ ) and adult (age $>18 ; n=26$ ). Thirtyeight of 50 patients were affected by unilateral MC impaction and six patients by bilateral impaction. Twenty-nine of the palatal-impacted MCs were on the left and twenty-one on the right side. However there were no supernumerary teeth or any pathology in any of the cases, twenty-five impermanent canines had retained. The age of the patients when they had surgical experience ranged from 13 to 42 years with a mean of $20 \pm 6,3$ years. In 6 patients' permanent teeth extraction was needed for the ideal treatment result. The treatment length was ranged from 16 to 36 months with a mean of $24,81 \pm 6,3$ months.

No irreversible surgical complication was encountered at the pre- and post-operative periods. The most frequently reported post-operative sequel was swelling which was started 24 hours after the surgery and continues 4-5 days postoperatively.

Forty-seven operated MCs were successfully aligned to the dental arch using the closed eruption technique. Three canines were extracted due to the resistance to the traction forces. In three cases, a second surgical operation was needed due to the breakage of the button. Lateral tooth root resorption was occurred in one lateral incisor and was treated with endodontic treatment successfully (Table 1).

Table 1: Complications seen in the overall treatment period.

\begin{tabular}{ll} 
Complications & Percentage \\
\hline Failed eruption/Extraction of the canine & $3(\% 6)$ \\
\hline Second surgery due to button breakage & $3(\% 6)$ \\
\hline Lateral tooth root resorption & $1(\% 2)$ \\
\hline Total & $7(\% 14)$ \\
\hline
\end{tabular}

No significant relation was found between the adolescent and adult patients by means of duration of orthodontic treatment $(p=0,28)$ and occurrence complication $(p=0,26)$ (Table 2). The measurement of the distance from the canine tip to its target point on the occlusal plane was found to be correlated positively with the duration of orthodontic treatment $(p=0,304 ; p=0,01)$. No statistical significance was found between the duration of the orthodontic treatment and other radiographic parameters including, canine angulation $(p=0,40)$, the mesiodistal position of the canine tip in relation to the neighboring teeth $(p=0,85)$, and the rate of root formation $(p=0,16)$. No significant relation was found between the complication rate and any of radiologic parameters including, canine inclination $(p=0,55)$, the mesiodistal position of the canine tip in relation to the neighboring teeth $(p=0,54)$, the rate of root formation $(p=0,34)$ and the measurement of the distance from the canine tip to its target point on the occlusal plane $(p=0,36)$.

Table 2: Demographic characteristics and complications that had been recorded in adult and young patients.

\begin{tabular}{|c|c|c|c|c|c|}
\hline & Age & Male/Female & Duration of canine alignment & Complication without fail & Fail \\
\hline Adult & $24.61 \pm 6(n=26)$ & $6 / 20$ & $23.88 \pm 5.96$ & 2 & 3 \\
\hline Adolescent & $15.91 \pm 1.7(n=24)$ & $6 / 18$ & $25.86 \pm 6.75$ & 2 & 0 \\
\hline
\end{tabular}




\section{Discussion}

The permanent canine teeth are very important for functional occlusion and esthetics. MCs are the second most frequently impacted tooth due to having a long developmental period, and the most devious path for occlusal plane. $(12,13)$. Prevalence of MCs impaction ranges from $1.0 \%$ to $2.5 \%(14,15)$ where $8.0 \%$ to $10.0 \%(4,16)$ of these cases are bilateral. In our study $7 \%$ of the cases had bilateral impacted MCs. The duration of treatment to obtain an optimal repositioning of the impacted MCs varies from about 21 to 28 months (17-19). Consistent with the literature the mean treatment duration in our case series was 24,8 months. Patients with impacted MCs seek treatment in a wide range of age group. There have been still controversies in the literature about the success of canine alignment in the adult patients with impacted canines. The literature reveals that; patient's age effects the success of the tooth movement (20). Cappellette et al. (21) reported that canine teeth can be brought into the arch by orthodontic traction following surgical procedure in patients aged 13 to 19 years, however success in elderly patients is lower due to ankylosis risk. Orton et al. (22) claims that the duration of treatments that begin after the end of the pubertal growth period will be longer. Motamedi et al. (7) evaluated 146 impacted canines that undergone surgical exposure and orthodontic alignment and reported that age had no influence on treatment results. However, their study group was consisting 87 cases with a relatively narrow age range of 18 to 24 years. In our study the age range was 13-42 years and we found no correlation between the age and treatment results. We also created two groups as young and adults according to the patients' ages. No differences were found between the young and adult patients by means of the treatment time, complication rate and failure.

In this study, we also aimed to investigate that the position of canine teeth in cephalometric and panoramic radiographs to predict treatment duration and prognosis. The canine angulation was measured with the angle between longitudinal axis and the vertical reference line. Previous studies reported that when the angulations of the impacted canines were increased, the total orthodontic treatment time was also increased $(23,24)$. The results of our study was contradicted with those past studies. We found no correlation between the canine angulation and the total orthodontic treatment time. It was estimated that the mesiodistal position of the canine tip in relationship to the adjacent lateral incisor is a marker for the treatment success. Motamedi et al. (7) reported that, if the overlap (>half the root) of the adjacent lateral incisor root via the canine crown is increased, it will influence the treatment results negatively. However, we found no significant effect of the canine's mesiodistal position on the treatment results. In this study the only radiologic parameter that was found to be related with the treatment duration, was the distance from the canine tip to its target point on the occlusal plane which was considered as mild correlation. None of other radiological parameters was found to be associated with the success and process of the treatment. Stewart et al. (19) suggested that the distance between the canine tip and occlusal plane might be a factor to estimate the treatment duration. They showed that the distance less than $14 \mathrm{~mm}$ exhibits treatment time around 24 months. The result of our study was in compatible with Stewart et al. (19) with an average measurement of the canine tip to its target point on the occlusal plane which was $9,6 \mathrm{~mm}$ and the total treatment time of 24,8 months.

Root resorption of the adjacent teeth occurs quite commonly when the incisors are close adjacent to impacted MCs. It was reported that physical proximity $(/ 1 \mathrm{~mm})$ between impacted MCs and adjacent roots is one of the most important predictor associated with root resorption of incisors and the first premolars. The increased risk of root resorption was associated with the eruption motion or migration of impacted MC during the incisors' root development process (25). When evaluated by cone beam computed tomography (CBCT), it was shown that between $27 \%$ to $38 \%$ of the adjacent laterals and $9 \%$ to $23 \%$ of adjacent centrals exhibited root resorption associated with the impacted canine tooth (26). Yan et al. (25) was investigated 170 patients with impacted MC and reported an overall prevalence rates of resorption $27 \%, 18 \%$ and $10 \%$ at the maxillary lateral incisor, the central incisor, and the first premolar, respectively. In our study root resorption was evaluated by panoramic and periapical radiographs and only $4 \%$ of adjacent root resorption were occurred during the treatment period. In our opinion the resorption rate might be found greater if the cases were evaluated with a 3-dimensional CBCT imaging techniques.

\section{Conclusion}

The following results may be drawn: [1] no relation was found between young and adult patients by means of treatment duration and prognosis, [2] the canine angulation and classification of mesiodistal position of the canine tip in relation to the adjacent lateral tooth is not related with treatment time and prognosis, [3] the distance of the canine tip to the occlusal plane on the lateral cephalometric radiographs have found to be more related with the total orthodontic treatment time than the radiographic and clinical parameters.

Türkçe Öz: Palatal gömülü maksiller kanin dişlerin ortodontik sürdürülmesinde yaş ve radyografik özellikler etkili midir? retrospektif bir çalışma. Amaç: Bu çalışmanın amacı, yaş ve radyografik parametrelerin palatal gömülü maksiller kaninlerin ortodontik hizalanmasının başarısına olan etkilerini araştırmaktır. Gereç ve Yöntem: Çalışmaya maksiller gömülü kanini olan 50 hastanın (ortalama yaş: 20.44) retrospektif kayıtları dahil edildi. Cerrahi işlem ve mekanik ortodontik sürdürme gereken palatal gömülü maksiller kaninleri olan hastalar adolesan (yaş 18, $n=24$ ) ve erişkin (yaş $=18 ; n=26$ ) olmak üzere iki gruba ayrıldı. Her iki grupta da tedavi süresi ve başarı klinik ve radyografik olarak değerlendirildi. Bulgular: Yaşları 13 ila 42 arasında ve palatal gömülü maksiller kanini olan 50 hasta (12'si erkek 38'i kadın) kombine cerrahi-ortodontik yaklaşımla tedavi edildi. Kırk yedi diş (\% 94) cerrahi olarak açığa çıkarılma ve ortodontik hizalamaya 16 ila 36 ay (ortalama 24.81 ay) içinde cevap vermiştir. Gömülü kaninlerden üçü 10 aylık çekme kuvvetini takiben hiçbir hareket gözlenmediğinden cerrahi olarak çıkarılmıştır. Sonuç: Lateral sefalometrik radyografilerdeki kanin dişi tepesinin oklüzal düzleme olan mesafesinin total ortodontik tedavi süresi ile ilişkili olduğu bulunmuştur. Maksiller dişlerin cerrahi olarak açığa çıkarılmasını takiben ortodontik hizalanmasında hastaların yaşı ya da diğer klinik ve radyografik parametler etkili değildir. Anahtar Kelimeler: Ortodontik hizalama; cerrahi açılma; gömülü maksiller kanin; radyografik çalışma; retrospektif çalışma. 
Ethics Committee Approval: The study protocol was approved by the ethics committee for medical research $(2012 / 522)$.

Informed Consent: Informed consents was provided by the participants' parents.

Peer-review: Externally peer-reviewed.

Author contributions: SK and BB designed the study. AO, NA and SKa participated in generating the data for the study. AO, NA and SKa participated in gathering the data for the study. BB participated in the analysis of the data. BB wrote the majority of the original draft of the paper. SK and AO participated in writing the paper. All authors approved the final version of this paper.

Conflict of Interest: The author had no conflict of interest to declare.

Financial Disclosure: The author declared that this study has received no financial support.

\section{References}

1. Rayne J. The unerupted maxillary canine. Dent Pract Dent Rec 1969;19:194-204.

2. Ericson S, Kurol J. Longitudinal study and analysis of clinical supervision of maxillary canine eruption. Community Dent Oral Epidemiol 1986;14:172-6. [CrossRef]

3. Grover PS, Lorton L. The incidence of unerupted permanent teeth and related clinical cases. Oral Surg Oral Med Oral Pathol 1985;59:420-5. [CrossRef]

4. Bishara SE. Impacted maxillary canines: a review. Am J Orthod Dentofac Orthop 1992;101:159-71. [CrossRef]

5. Nordenram A. Impacted maxillary canines. A study of surgically treated patients over 20 years of age. Swed Dent J 1987;11:153-8.

6. Shapira $Y$, Kuftinec MN. Early diagnosis and interception of potential maxillary canine impaction. J Am Dent Assoc 1998;129:1450-4. [CrossRef]

7. Motamedi MH, Tabatabaie FA, Navi F, Shafeie HA, Fard BK, Hayati Z. Assessment of radiographic factors affecting surgical exposure and orthodontic alignment of impacted canines of the palate: a 15-year retrospective study. Oral Surg Oral Med Oral Pathol Oral Radiol Endod 2009;107(6):772-5. [CrossRef]

8. McSherry PF. The ectopic maxillary canine: a review. Br J Orthod 1998;25:209-16. [CrossRef]

9. Nieri M, Crescini A, Rotundo R, Baccetti T, Cortellini P, Pini Prato GP. Factors affecting the clinical approachto impacted maxillary canines: a Bayesian network analysis. Am J Orthod Dentofacial Orthop 2010;137:755-62. [CrossRef]

10. Stivaros N, Mandall NA. Radiographic factors affecting the management of impacted upper permanent canines. J Orthod 2000;27:169-73. [CrossRef]

11. Lindauer SJ, Rubenstein LK, Hang WM, Andersen WC, Isaacson RJ. Canine impaction identified early with panoramic radiographs. J Am Dent Assoc 1992;123(3):91-7. [CrossRef]
12. Ferguson JW. Management of the unerupted maxillary canine. Br Dent J 1990;169:11-7. [CrossRef]

13. McDonald F, Yap WL. The surgical exposure and application of direct traction of unerupted teeth. Am J Orthod 1986;89:331-40. [CrossRef]

14. Grover PS, Lorton L. The incidence of unerupted permanent teeth and related clinical cases. Oral Surg Oral Med Oral Pathol 1985;59:420-5. [CrossRef]

15. Thilander $B$, Jakobsson SO. Local factors in impaction of maxillary canines. Acta Odontol Scand 1968;26:145-68. [CrossRef]

16. Quirynen M, Op Heij DG, Adriansens A, Opdebeeck HM, van Steenberghe D. Periodontal health of orthodontically extruded impacted teeth. A split-mouth, long-term clinical evaluation. J Periodontol 2000;71:1708-14. [CrossRef]

17. Crescini A, Nieri M, Buti J, Baccetti T, Mauro S, Prato GP. Short and long term periodontal evaluation of impacted canines treated with a closed surgical-orthodontic approach. J Clin Periodontol 2007;34(3):232-42. [CrossRef]

18. Iramaneerat $\mathrm{S}$, Cunnigham SJ, Horrocks E. The effect of two alternative methods of canine exposure upon subsequent duration of orthodontic treatment. Int J Paediatr Dent 1998;8:123-9. [CrossRef]

19. Stewart JA, Heo G, Giover KE, Williamson PC, Lam EWN, Major PW. Factors that relate to treatment duration for patients with palatally impacted maxillary canines. Am J Orthod Dentofacial Orthop 2001;119:216-25. [CrossRef]

20. Machen DE. Legal aspects of orthodontic practice: risk management concepts. The impacted canine. Am J Orthod Dentofacial Orthop 1989;96:270-1. [CrossRef]

21. Cappellette $M$, Cappellette $M$ Jr, Fernandes LCM, de Oliveira AP, Yamamoto LH, Shido FT, de Oliveira WC. Palatine impacted permanent maxillary canines: diagnose and therapeutics. $\mathrm{R}$ Dent Press Ortodon Ortop Facial 2008;13:60-73. [CrossRef]

22. Orton HS, Garvey MT, Pearson MH. Extrusion of the ectopic maxillary canine using a lower removable appliance. Am J Orthod Dentofacial Orthop 1995;107:349-59. [CrossRef]

23. Bazargani F, Magnuson A, Dolati A, Lennartsson B. Palatally displaced maxillary canines: factors influencing duration and cost of treatment. Eur J Orthod 2013;35:310-6. [CrossRef]

24. Zuccati G, Ghobadlu J, Nieri M, Clauser C. Factors associated with the duration of forced eruption of impacted maxillary canines: a retrospective study. Am J Orthod Dentofacial Orthop 2006;130(3):349-56. [CrossRef]

25. Yan B, Sun Z, Fields H, Wang L. Maxillary canine impaction increases root resorption risk of adjacent teeth: a problem of physical proximity. Am J Orthod Dentofacial Orthop 2012;142(6):750-7. [CrossRef]

26. Liu DG, Zhang WL, Zhang ZY, Wu YT, Ma XC. Localization of impacted maxillary canines and observation of adjacent incisor resorption with cone-beam computed tomography. Oral Surg Oral Med Oral Pathol Oral Radiol Endod 2008;105:91-8. [CrossRef] 